\title{
Econometric Analysis of the Effects of Corruption on Government Tax Revenue: Evidence from Panel Data in Developed and Developing Countries
}

\author{
Gedefaw Abebe $^{1, \grave{\dagger}, *}$, Seyfe Fikre ${ }^{2, \dagger}$ \\ ${ }^{1}$ Department of Agricultural Economics, College of Agriculture and Natural Resource, Bonga, University, Bonga, Ethiopia \\ ${ }^{2}$ Department of Economics, Collage of Business and Economics, Bonga, University, Bonga, Ethiopia \\ Email address: \\ abebegedefaw@gmail.com (G. Abebe), seyfefikre2008@gmail.com (S. Fikre) \\ ${ }^{*}$ Corresponding author \\ $\dagger$ Gedefaw Abebe and Seyfe Fikre are co-first authors.
}

\section{To cite this article:}

Gedefaw Abebe, Seyfe Fikre. Econometric Analysis of the Effects of Corruption on Government Tax Revenue: Evidence from Panel Data in Developed and Developing Countries. European Business \& Management. Vol. 6, No. 2, 2020, pp. 28-35. doi: 10.11648/j.ebm.20200602.12

Received: May 25, 2020; Accepted: June 8, 2020; Published: June 20, 2020

\begin{abstract}
Corruption and tax evasion remain main problems in both developed and developing countries. So, contribution of this study was to extend the conventional determinants of tax revenue over gross domestic product not only supply factor but also demand factor such as corruption, political stability, and rule of low which determine the tax revenue over gross domestic product to a significant extent. Panel regression model was used for analysis. Panel data were collected from 33 developing and developed countries for the period of 2002-2017. The data sets which were used in model analysis were obtained from the database of the world development indicators. As the fixed effect regression result indicates corruption has significant adverse effect on government tax revenue over gross domestic product in both developed and developing countries. The least corrupted countries collect $6 \%$ more tax revenue than high corrupted countries. The great progress in corruption has to be monitored and reduced. So, corruption no longer considered as an exogenous factor in an economy, it should be considered as a controlled and minimized phenomenon by the democratic institution and civil society. Therefore legislative reforms have to be continued in order to diminish corruption.
\end{abstract}

Keywords: Developed and Developing Countries, Effect of Corruption, Panel Data, Tax Revenue over GDP

\section{Introduction}

Corruption is misuse of public resource for private purpose [8]. Misallocation of public resource leads to a loss of resource available to the government for financing its expenditure. Corruption may also cause a general misallocation of public expenditure as certain area of spending, which may limit the flow of resource like trade openness and resulted in inflation [1]. Corruption is a moral problem in cultural and individual sense as well as in economic and political life. In this sense, corruption is a sociological fact in terms of ethics and it is also dealt with as an economic fact due to its effects on social welfare and development [4]. Corruption roots are extended in countries due to historical, cultural, political factors.

Seldadyo et al [22] argued that the factors that affect corruption could be explained in to economic factor, economic institution and demographic factor. The economic factors are included the level of income, income distribution, government revenue, expenditure and inflation are some of the factor that extends the root of corruption. Distorted economic institution also increases the level of corruption. Corruption leads deep institutional weaknesses and inefficient economic, social, and political outcomes. Akçay [5] argued that corruption reduces economic growth, retards long-term foreign and domestic investments, enhances inflation, depreciates national currency, reduces expenditures for education and health, increases military expenditures, misallocates talent to rent-seeking activities, pushes firms underground, distorts markets and the allocation of resources, increases income inequality and poverty, reduces tax revenue, increases child and infant mortality rates, distorts 
the fundamental role of the government (on enforcement of contracts and protection of property rights), and undermines the legitimacy of government and of the market economy.

Corruption reduces the flow of Foreign Direct Investments (FDI) $[6,24]$, it erodes the overall institution integrity [11] and exacerbates the extent of income inequality [23] and corruption has negative effect on economic growth this leads human capital and political instability [13].

Hwang [17] revealed that corrupt politician may distort international trade by using their authorities in the way to increase tax in international trade for their gains, which leads to increase the price level for the user of that imported product.

Corruption can be effective in creation of inflation tax though budget deficit [1]. Corruption leads to high level of public deficits and ineffective tax system in a country. Government generates income through monetization of fiscal deficits under the name of seignior age and inflation tax. Wrong macroeconomic policies pursued to finance high public expenditures cause high budget and current account deficits and trigger inflation [21].

Empirical studies were done on the interaction of corruption with inflation $[4,1,3,10])$ and corruption with tax revenue separately [14]; Brasovanu et al., 2010; [17], even though the disruption of corruption leads weak economic growth and high income inequality. Therefore this study was aimed to identify impact of corruption on government tax revenue by taking sample 33 countries from both developing and developed countries for the period (2002-2017). Having in mind this, the objective of the study was to investigate and test the relationship between corruption and tax revenue.

\section{Literature Review}

Several studies have been under taken to provide an understanding of the impact of corruption on the economy. Some of them are summarized as follow:

Acka et al [4] tested the relationship between inflation and corruption in 97 countries for the year 2002- 2012 through panel with random effect method. The corruption index was used as a dependent variable in their model. The variable inflation, gross domestic product growth rate, political stability, role of low, accountability was used as independent variable. In their study reached in an increase in the rate of inflation which brings an increase in the rate of corruption. Ahmad et al [2] dealt with the relationship between control of corruption and inflation for 40 developing countries through panel data for the period 2003- 2010. Inflation tax was used as a dependent variable and control of corruption index, ratio of foreign trade to GDP, inflation tax with a lag used as independent variable. Their study revealed that a more increase at controlling of the corruption in a country contribute to reduce inflation tax. On the other hand, positive relation was observed in inflation tax and extent of corruption.

Ajaz et al [3] analyzed the factor affecting the government tax revenue using panel data for 25 developing countries in the year 1990-2005. The study was analyzed using generalized method of moment by using tax revenue over GDP as a dependent variable and corruption index, trade openness and governance as independent variable. The result revealed that corruption has negative effect on tax revenue, while good governance has positive effect of tax revenue.

Akçay [5] investigated the relationship between corruption and human development using ordinary least square method data obtained from 63 countries for the year 1991-1997. He used human development index as a dependent variable and corruption index, economic freedom, democracy and urbanization as independent variable. His study revealed that there is a statistically significant negative relationship between corruption indexes and human development. The study suggests that more corrupt countries tend to have lower levels of human development. Brasoveanu et al [9] investigated the relationship between corruption and overall tax burden through correlation analysis in the member of European Union from 27 countries for the year 1995-2008. The level of corruption was measured by the corruption index and tax burden was measured by fiscal revenue over GDP. The study found that coefficient of correlation between corruption and tax revenue over Gross Domestic Product (GDP) was negative. Braun and Di Tella [10] tested the interaction between inflation and corruption in 75 countries for the year 1982 -1994 through panel data with least squares method. The corruption index of ICRG was used as the dependent variable in the model. The variable of information, Rents and control as a proxy of were used as independent variables. The researchers reached in their study that the change (the increase) in the rate of inflation caused a positive and statistically significant effect on corruption.

Dridi [13] corruption has negatively affected economic growth. He was used panel data of 82 countries obtained from developed and developing countries for the period of 1980-2002. The study tried to identify the transmission channel through which corruption is likely to affect economic growth. The negative effect of corruption on economic growth is mainly transmitted by its impact on human capital and political instability. Gawewopo [14] tested the interaction among corruption, taxation and economic growth in 97 countries for the period 1980- 2002 using generalized method of moments. His finding revealed that corruption has two effects on growth, a negative direct effect lowering both tax revenues and public expenditure, and an indirect positive effect positive once the adverse effects are accounted for. But he concludes that in countries with high corruption, the negative impact of public resources on growth is greater.

Hwang [17] dealt with the relationship between corruption and government revenue in his study. He investigated the effect of corruption on government revenue in 41-66 countries for the year in 1999 using OLS method and cross sectional analysis. Hwang took factor such as tax revenue over GDP, total amount of government revenue over GDP in to the extent of this analysis. Here a country with high level of corruption has smaller volume of government revenue in general and smaller volume of tax revenue in particular. 
IMF [18] investigates the effect of corruption on state capacity to raise revenue for 147 countries for the period1995-2014. The finding revealed that corruption has considerable adverse impact on aggregate revenue performance as much as 0.6 percent of GDP annually.

Ozsahin et al [21] tested the direction of the effects of corruption on inflation by using the data from 20 selected developing countries for the period 1995-2015. The finding of the study pointed to a significant and positive impact corruption of on the high level of the inflation rate.

Moreover corruption and inflation have significant positive relationship [4, 1, 10] and significant negative impact on government tax revenue $[3,18,19]$ revealed the cost of corruption for the economy substantial.

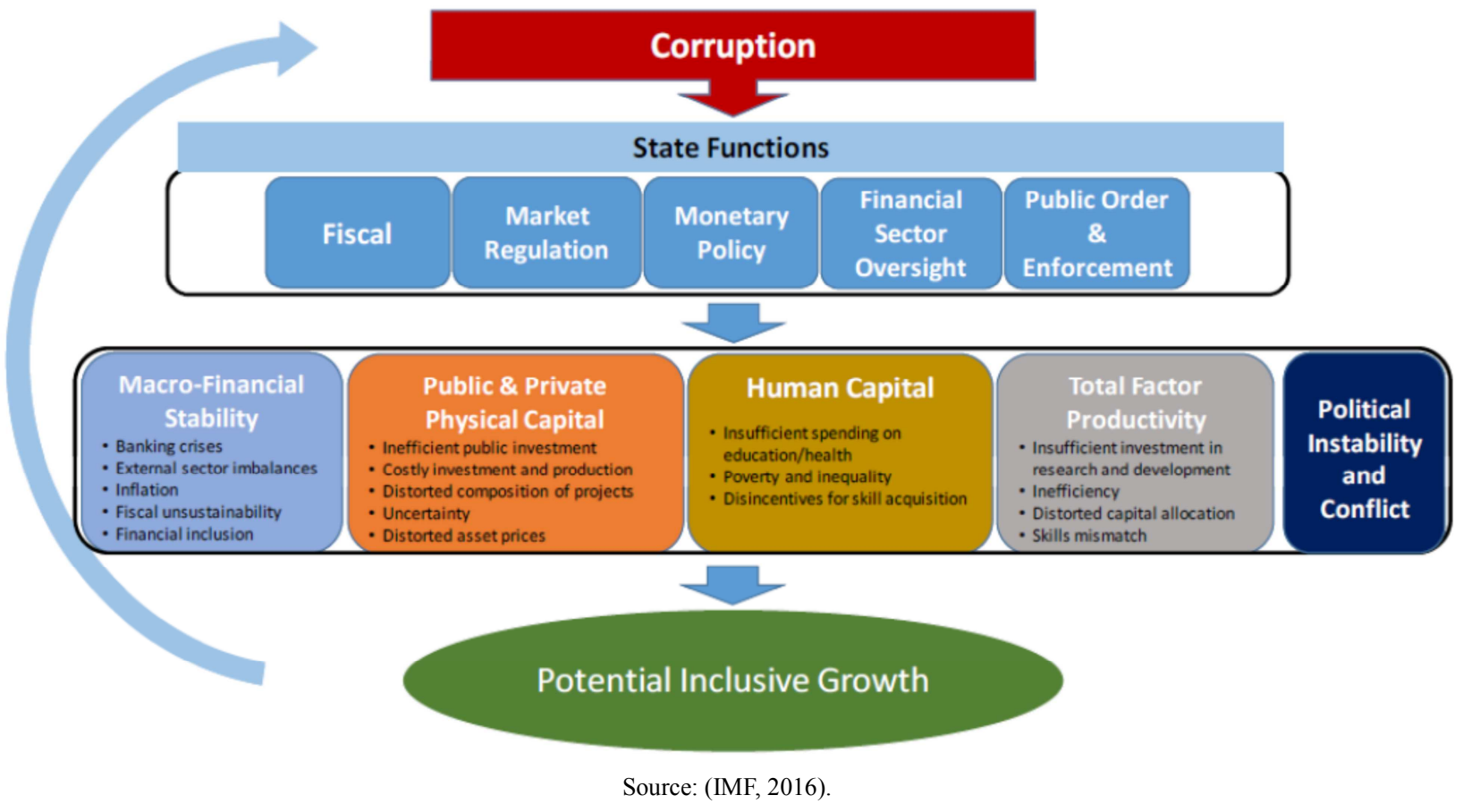

Figure 1. Corruption growth nexus.

The figure above revealed that substantial impact of corruption on the overall economy. Corruption has negative effects on key channels that affect growth. It breeds public distrust in government and weakens the state's capacity to perform its core functions. As corruption erodes the state's ability to collect revenue, the government becomes more reliant on seignior age finance which leads to inflation. This can be a two-way relationship, from inflation to corruption and from corruption to inflation. The common belief in the relationship from inflation to corruption is that the increase and rapid change in inflation results in escalation in corruptions and the inverse's also true, which implies high level of corruption, paves the way for inflation. Corruption can raise the general level of prices as an additional cost element [4].

\section{Methodology}

\subsection{Research Design}

The study was aimed to investigate the relationship between tax revenue and corruption, and the effect of political stability, role of low, GDP growth on tax revenue. The panel data method which has lots of advantages is preferred more and more in both macro and micro level econometric studies [15].
Since panel data relate to individuals, firms, states, countries, etc., over time, there is bound to be heterogeneity in these units. The techniques of panel data estimation can take such heterogeneity explicitly into account by allowing for individual-specific variables, as we shall show shortly. We use the term individual in a generic sense to include micro units such as individuals, firms, states, and countries [16].

By combining time series of cross-section observations, panel data give "more informative data, more variability, less co-linearity among variables, more degrees of freedom and more efficiency." By studying the repeated cross section of observations, panel data are better suited to study the dynamics of change $[16,4]$. Panel data regression model is shown below in the simplest way [15]:

$$
y i t=x i t \beta+z i \alpha+\varepsilon i t, \text { where }(1=1, \ldots, N, t=1, \ldots, J)
$$

$\mathrm{x}_{\mathrm{it}}$ expresses $\mathrm{K}$ (amount) variables that do not include fixed term. In $Z_{i}$ a term which shows heterogeneity and individual effects, $z_{i}$ expresses the observable effects such as race, gender and place or non-observable individual or group specific effects. The model depending on the assumption of made about fixed term, slope coefficient and error term. In a fixed term model the $\varepsilon i$ are assumed to be fixed parameters to be estimated and the remainder disturbances stochastic with $\mathrm{v}_{\text {it }}$ independent and identically distributed IID $\left(0, \sigma^{2}\right)$ 
[7]. The term "fixed effects" is due to the fact that, although the intercept may differ across individuals, each individual's intercept does not vary over time; that is, it is time invariant. In the random effects model, however; it is accepted that the differences between the sections are accidental and each section is allowed to have different fixed terms [16].

Panel least squares model (LSV) is a very limited model as it does not take effects that are private for each section into consideration. On the other hand, if you are certain that the neglected fixed effects and random effects are independent, using the panel least squares method will provide more accurate results. For this reason, the homogeneity of the effects belonging to the countries would be tested through Lagrange Multipliers (LM) test [4]. For the choice of fixed effect or random effect the study test the error term weather its correlated or not with explanatory variables through Hausman test.

\subsection{Panel Data Set}

The effect of corruption on tax revenue in three different group levels according to their income level through panel data was analyzed. The discrimination that is made by World Bank, the first group consists of 13 high income countries that is made by the World Bank, with over \$ 12275 income; the second groups consists of 10 middle-income countries with $\$ 1005-\$ 12275$ income and the third group consists of 10 low-income countries with below $\$ 1005$ income. As analyzing the years before 2002 results in the decrease in the amount of cross sections, the period 2002-2017 was selected as the research period and a balanced panel was established with reference to annual data of this period. The data sets which were used in model analysis were obtained from the database of the World Development Indicators (WDI) [25].

\subsection{Panel Regression Model Equation}

$$
\text { Tax revenue }{ }_{\mathrm{it}}=\lambda_{1} \text { corrpt }_{\mathrm{it}}+\mathrm{Z}_{\mathrm{i} 1} \alpha_{1}+\mu_{\mathrm{i} 1}
$$

In the effects of corruption on tax revenue equation, Corr indicate corruption index (endogenous), $Z_{\mathrm{i} 1}$ exogenous and observed variable that would affect tax revenue, $\mu_{\mathrm{i} 1}$ unobserved variable that would affect tax revenue. In the regression equation two above, the subscript of (i) expresses the country, the subscript of (t) expresses the tax revenue growth within the time period for the country at time $t$. corrpt $_{\mathrm{it}}$ indicates the corruption index, indicates the extent of corruption in (i) country at time t. The variable of consists of exogenous variables of which are thought to be related with the overall economic growth and with the control of corruption in the countries. Summary information and descriptive statistics about the variables are shown in Table 1.

Table 1. Variable description.

\begin{tabular}{lll}
\hline Abbreviation & Variable & Description \\
\hline Taxrev & Tax revenue & The growth of tax revenue over GDP \\
Inflation & Inflation with consumer prices (annual \%) & The annual inflation rate with consumer prices \\
CORRUP & The index of corruption control & The index value that shows the public power against corruption \\
GDPGRO & The growth in gross domestic product (annual \%) & It shows the annual growth in gross domestic product \\
POLSTA & The index of political stability & It is the index in which the political stability of governments is measured. \\
RULE & The index of the rule of law & The index values about the society's keeping the rules, the frequency of crime \\
Log of FDI & Logarithm of net FDI flows & and violence, the quality of police and court services \\
\hline
\end{tabular}

Source: (WDI, 2019).

The corruption control index is measured by transparency international range from zero (high corrupted) to 100 (least corrupted). Because of this contradiction, all of the scores subtracted from 100, so the higher scores represent the maximum amount of corruption and the lower scores show the minimum amount of corruption in the country. Rule of Law captures perceptions of the extent to which agents have confidence in and abide by the rules of society, and in particular the quality of contract enforcement, property rights, the police, and the courts, as well as the likelihood of crime and violence. Estimate gives the country's score on the aggregate indicator, in units of a standard normal distribution, i.e. ranging from approximately -2.5 (low score) to 2.5 (high score). Political stability and absence of violence/terrorism measures perceptions of the likelihood of political instability and/or politically-motivated violence, including terrorism. Estimate gives the country's score on the aggregate indicator.

\section{Results}

\subsection{Diagnosis Tests}

Before data analyzed the overall credibility of the result was tested. Since $\mathrm{R}^{2}$ is not accurate measurement of the quality of the model, $\chi^{2}$ statistic for Wald test on the null hypothesis that all the slope coefficients were equal to zero, The value of $\chi^{2}$ statistics were highly significant, confirming that the overall fit of the equations was quite satisfactory.

The model was based on the assumption of the error term so as to predict the relationship between variables. Pooled OLS, fixed effects and random effects are appropriate for panel data. The technique for choosing the appropriate method was tested using LM test which tests the homogeneity of the country effects. The null hypothesis in which random effect model turns into pooled regression model was tested, if the variance of the unit effects is found as zero through LM test.

H0: Pooled Regression, $\sigma 2 \alpha=0$ 


\section{H1: Random Effect, $\sigma 2 \alpha>0$}

The study run these test and found rejection of the null hypothesis, indicate the model cannot be predicated with pooled regression (the statistics of tests related with the models are shown in Appendix). The study was predicted through fixed effects first, and then it was tested through Hausman test, in deciding between fixed effects or random effects. The Hausman test found out whether the error term in the model related with independent variable in order to use more accurate method. According to Gujarati [16], if the individual error component $\varepsilon_{\mathrm{i}}$ and one or more regressors are correlated, then the Random Effect model estimators are biased, whereas those obtained from fixed effects model are unbiased. If the null hypothesis is rejected, the conclusion is that Random Effect Model is not appropriate and that we may be better off using fixed effects model. According to the results of these two tests, fixed effects model provides the most reliable predictions.

\subsection{Descriptive Result}

The descriptive statistics for government tax revenue and corruption index were explained in table below. The table showed that least corrupted countries collect $6 \%$ more tax revenue over their GDP than high corrupt countries.

Table 2. Descriptive statistics.

\begin{tabular}{llll}
\hline Variable & Low income countries (10 countries) & Middle income countries (10 countries) & High income countries (13 countries) \\
\hline Tax revenue/GDP & 12.3 & 16.9 & 19.0 \\
Corruption index & 72.3 & 40.4 & 21.7 \\
\hline
\end{tabular}

Own survey (2019).

\subsection{Econometrics Result}

Table 3. Panel data prediction result.

\begin{tabular}{llll}
\hline Dependent & Growth of tax revenue over GDP & & \\
\cline { 2 - 4 } Variable & Model I Low income countries & Model II Middle income countries & Model III High income countries \\
\hline CORRUP & $-0.1065(-1.79)^{* *}$ & $-0.1381(-2.42)^{* *}$ & $-0.3143(-2.05)^{* *}$ \\
GDPGR & $-0.0744(-0.86)$ & $0.12435(1.05)$ & $-1.4065(-2.39)^{* *}$ \\
POLSTA & $3.3973(7.40)^{* *}$ & $4.2079(5.70)^{* *}$ & $-5.6344(-1.92)$ \\
RULE & $4.8070(4.67)^{* *}$ & $3.2606(2.78)^{* *}$ & $-1.5453(-0.35)$ \\
LogFDI & $-0.1009(-0.55)$ & $7.5900(3.09)^{* *}$ & $-3.2536(-6.7)^{* *}$ \\
Constant & $22.2010(4.43)^{* *}$ & $25.4002(7.71) * *$ & $112.0085(7.53)^{* *}$ \\
The number of Observations & 150 & 150 & 195 \\
The number of Countries & 10 & 10 & 13 \\
F Statistics & 17.07 & 29.04 & 12.56 \\
P value (F statistics) & $0.0000^{* *}$ & $0.0000 * *$ & $0.0000^{* *}$ \\
$R^{2}$ & 0.4895 & 0.5346 & 0.3174 \\
\hline
\end{tabular}

The values in brackets indicate t-statistics.

Note: $* * \& *$ indicates at $5 \%$ and $10 \%$ level of significance in sequence.

As the panel data regression result indicates, high growth of tax revenue over GDP negatively associated with corruption index in all three income groups. High-level corruption reduces tax revenue. Accordingly, an increase in the rate of corruption brings a decrease the rate of tax revenue growth in these three groups of countries which are investigated in the scope of this analysis. A one-point increase in the corruption index reduces tax revenue collected by $10 \%, 13 \%$ and $31 \%$ of GDP in low income, middle income and high income countries respectively. The result is in line with a prior expectation and previous study [18, 3, 9, 17]) that corruption cause significant leakages in tax revenue.

Furthermore, the relationship between dependent variable and other explanatory variables were found: the growth of GDP in high income countries has negative relation with government tax revenue growth, but positive and insignificant effect on low and income countries. The result of the study was found in contrary with the expectation. The possible reason might be government spending will be important source of promoting the country economic growth through promoting investment.
Increasing tax means discouraging the level investment which intern further decline the government tax revenue over GDP.

Political Stability (POLSTA) which is a bigger issue in low and middle-income countries than in high-income countries tax revenue over GDP and the prediction result introduced that the effect of political stability on tax revenue to GDP is important. Good political condition increase the tax revenue over GDP in low and middle countries by 3.4 and 4.2 units respectively. Political stability condition is not an issue in high income countries and it has insignificant relationship with their tax revenue over GDP.

The relationship between the Rule of Law (RULE) and tax revenue was found as positive and statistically significant in low-income and middle income countries. Active law systems will ensure accountability and transparency power to control the tax evasions that are possible in the execution system.

The relationship between the log of net FDI and tax revenue to GDP was negative and significant relation in low and high income countries, but positive and 
significant effect on middle income countries. Low income countries characterized with unsuitable government policy resulted in outflow of resource to abroad and in high income countries there is high level of outflow of investment for a better profit and access to row material in less developed countries. Therefore, their net investment become negative leads to decrease the government tax revenue over GDP. But in middle income countries net foreign direct investment is positive due to favorable condition and it has significantly contribute to the government tax revenue.

\section{Conclusion and Recommendations}

As fixed effect panel regression result indicates corruption has significant effect on government tax revenue over GDP and also least corrupted countries collect $6 \%$ more tax than high corrupt countries. Corruption erodes the government tax revenue growth over GDP in both developing and developed countries by creating a negative effect on the investors and the retardation in economic growth. A possible interpretation of the observed association between corruption and the distortion of government revenue is that corrupt governments find it is easier to collect bribes on some activities than on others. The political stability and rule of low have been the agenda in low income and middle income countries. Political instability leads to outflow of resource and distort the entire economy of the country. As the result indicates good political condition and keeping rule of low has positive effect on government tax revenue over GDP. Stable political condition attracts investor to invest their resource, which intern rise the government revenue through tax. Corruption and tax evasion remain main problems in the world. The great progress in corruption has to be monitored and reduced. So, corruption no longer considered as an exogenous factor in an economy, it should be considered as a controlled and minimized phenomenon by the democratic institution and civil society. Therefore legislative reforms have to be continued in order to diminish corruption.

\section{Appendix}

\section{Appendix 1: Countries Examined in the Analysis}

Table A1. Low-Income Countries, Middle income countries, High-Income Countries.

\begin{tabular}{lll}
\hline Low-Income Countries (Below \$ 1,005) & Middle income countries (between \$ 1005 and & High-Income Countries (Over \$ 12,275 income) \\
\hline A 12275) & US \\
Anghanistan & Brazil & Swizerlands \\
Central Africa & Cote d'ivore & Sweden \\
Ethiopia & Egypt & Spain \\
Mali & India & Norway \\
Nepal & Kenya & Japen \\
Rwanda & Mauritius & Italy \\
Tanzania & Namibia & Germeny \\
Togo & Uruguay & Frence \\
Afghanistan & Botsewana & UK \\
& Argentina & Denmark \\
& & Canada \\
\hline
\end{tabular}

Appendix 2: Descriptive Statistics

Table A2. Low income countries.

\begin{tabular}{|c|c|c|c|c|c|}
\hline Variable & Mean & Standard deviation & Minimum & Maximum & Number of Observations \\
\hline TaxR/GDP & 12.33015 & 4.41435 & 1.778667 & 29.24668 & 150 \\
\hline CORRUP (100-corr. Index) & 72.23115 & 8.570508 & 45 & 92 & 150 \\
\hline GDPGR & 5.543086 & 4.876085 & -36.03743 & 21.39053 & 150 \\
\hline POLSTA & -1.012057 & .858962 & -2.800609 & .4532746 & 150 \\
\hline RULE & -.7413867 & .4586564 & -1.896632 & .1286223 & 150 \\
\hline LogFDI & 18.58412 & 1.948195 & 12.04355 & 23.02867 & 150 \\
\hline
\end{tabular}

Table A3. Middle income countries.

\begin{tabular}{|c|c|c|c|c|c|}
\hline Variable & Mean & Standard deviation & Minimum & Maximum & Number of Observations \\
\hline TaxR/GDP & 17.03773 & 6.076927 & 8.079454 & 33.64857 & 150 \\
\hline CORRUP (100-corr. Index) & 59.52359 & 14.46118 & 26 & 81 & 150 \\
\hline GDPGR & 3.891391 & 3.619596 & -10.89448 & 12.26955 & 150 \\
\hline POLSTA & -.1528468 & .9777996 & -2.264047 & 1.200234 & 150 \\
\hline RULE & -.0554464 & .650467 & -1.479573 & 1.07713 & 150 \\
\hline LogFDI & $-7.82 \mathrm{e}+09$ & $1.60 \mathrm{e}+10$ & $-9.05 e+10$ & $9.42 \mathrm{e}+09$ & 150 \\
\hline
\end{tabular}


Table A4. High income countries.

\begin{tabular}{llllll}
\hline Variable & Mean & Standard deviation & Minimum & Maximum & Number of Observations \\
\hline TaxR/GDP & 19.0061 & 7.724706 & 7.919616 & 36.50029 & 195 \\
CORRUP (100-Corr. Index) & 21.74196 & 12.63519 & 2 & 61 & 195 \\
GDPGR & 1.715581 & 1.875317 & -5.61886 & 5.991968 & 195 \\
POLSTA & .8143591 & .4333916 & -.4737767 & 1.610245 & 195 \\
RULE & 1.585864 & .4111994 & .2467615 & 2.096355 & 195 \\
LogFDI & 23.71535 & 1.273605 & 20.4279 & 25.90098 & 195 \\
\hline
\end{tabular}

Appendix 3: F, LM and Hausman Tests

Table A5. Model I, Model II and Model III Wald F-test and fixed effects result.

\begin{tabular}{llll}
\hline \multirow{2}{*}{ Model I } & Wald F-test & $\mathbf{3 1 5 . 6 * *}$ & Fixed effects \\
\cline { 2 - 4 } & Breusch-Pagan & $198.23^{* *}$ & Random effects \\
& Hausman & $7.82^{* *}$ & Fixed effects/Random effects \\
Model II & Bald F-test & $324.5^{* *}$ & Fixed effects \\
& Hausch-Pagan & $224.61^{* *}$ & Random effects \\
& Wald F-test & $9.17 * *$ & Fixed effects/Random effects \\
Model III & Breusch-Pagan & $416.03^{* *}$ & Fixed effects \\
& Hausman & $65.27041^{* *}$ & Random effects \\
\hline
\end{tabular}

\section{References}

[1] Ahmad J., Maryam A, and Mehrnoosh, A (2012). Corruption and Inflation Tax in Selected Developing Countries. MiddleEast Journal of Scientific Research 11 (3): 391-395.

[2] Ahmad, J, and Maryam, A. (2012), Control of corruption and inflation tax: new evidence from selected developing countries. Procedia Social and Behavioral Sciences $62 \mathrm{pp}$. 441-445.

[3] Ajaz, T. And Ahmad, E., (2010). The effect of corruption and governance on tax revenues The Pakistan development reviews 49: 4 Part II, Pp. 405-417.

[4] Akça, H., Ata A. Y. and Karaca C. (2012), Inflation and Corruption Relationship: Evidence from Panel Data in Developed and Developing Countries. International Journal of Economics and Financial Issues Vol. 2 (3), pp. 281-295.

[5] Akçay S., (2006), Corruption And Human Development. Cato Journal, Vol. 26 (1).

[6] Ali Al-Sadig, (2009). The Effects of Corruption on FDI Inflows. Cato Journal, Vol. 29, No. 2

[7] Baltagi, B. H. (2005), Econometric Analysis of Panel Data. Third Edition, John Wiley \& Sons Ltd., West Sussex, England.

[8] Blackburn, K \& Powell, J (2011). Corruption, inflation and growth' Economics Letters, vol. 113, no. 3, pp. 225-227.

[9] Brasoveanu, I. V. and Brasoveanu L. O., (2010). Correlation between corruption and tax revenues. The Bucharest Academy of Economic Studies.

[10] Braun, M., and Di Tella, R. (2001). Inflation and Corruption. Economics \& Politics.

[11] Brock, G. N. (2014). Institutional Integrity, Corruption, and Taxation. Edmond J. Safra Working Papers, 2 (3), 1-54.
[12] Cukierman A., Edwards S., And Tabellini G. (1989). Seignorace and political instability national bureau of economic research working paper No. 3199, Massachusetts Avenue.

[13] Dridi, M, (2013). Corruption and Economic Growth: The Transmission Channels Faculty of Economic Sciences and Management. University of Sousse, Tunisia.

[14] Gbewopo A (2011). Corruption, taxation and economic growth: theory and evidence. 2011. HAL Id: halshs-00556668.

[15] Greene, W. (2002). Econometrics analysis. 5th Ed. New York, NY: prentice-Hall.

[16] Gujarati, D. N. (2004). Basic Econometrics. 4th ed. New York, NY: McGraw-Hill.

[17] Hwang, J. (2002). A Note on the Relationship between Corruption and Government Revenue. Journal of Economic Development Vol. 27 (2).

[18] IMF (2017). Corruption, Taxes and Compliance. Prepared by Baum, A., Gupta, S., Kimani, E. and Tapsoba, S. J. Working paper.

[19] IMF (2016). Corruption: Costs and Mitigating Strategies. Fiscal Affairs and Legal Departments. Staff Team from the Fiscal Affairs Department and the Legal Department.

[20] M Braun, M. and Di Tella, R., (2000). Inflation and Corruption. Harvard Business School, MA 02163, US.

[21] Öz,Sahin S. and Üçler G., (2017). The consequences of corruption on inflation in developing countries: evidence from panel co-integration and causality tests Economies vol. 5 (49).

[22] Seldadyo, H. and Haan J. (2006). The Determinants of Corruption A Literature Survey And New Evidence. Paper Prepared for the 2006 EPCS Conference, Turku, Finland.

[23] Sulemana I. and Kpienbaareh, D. (2018). An empirical examination of the relationship between income inequality and corruption in Africa. Economic Analysis and Policy, PP. $27-42$. 

Evidence from Panel Data in Developed and Developing Countries

[24] Tosun, O., yurdakul M. onur, iyidoğan, P.(2014). The relationship between corruption and foreign direct investment inflows in turkey: an empirical examination. Transylvanian Review of Administrative Sciences, No. 42.
[25] World Development Indicators (WDI) http://data.worldbank.org/indicato.

2019. 